\title{
А.Л. Торопов
}

\section{КОМБИНИРОВАННЫЕ ТЕПЛОВЫЕ ГЕЛИОСИСТЕМЫ}

Часть 2

Тепловые аккумуляторы, бойлеры косвенного нагрева индивидуальных и децентрализованных систем отопления и горячего водоснабжения

Учебное пособие 
УДК 621.499

ББК 31.368

T61

\section{Торопов А.Л.}

T61

Комбинированные тепловые гелиосистемы. Ч. 2. Тепловые аккумуляторы, бойлеры косвенного нагрева для индивидуальных и децентрализованных систем отопления и горячего водоснабжения: учебное пособие. - М.: Издательский дом Академии Естествознания, 2019. - 44 с.

\section{ISBN 978-5-91327-576-9}

\section{DOI 10.17513/np.348}

Учебное пособие посвящено низкотемпературным емкостным и фазовопереходным тепловым аккумуляторам, бойлерам косвенного нагрева, приборам, которые широко используются в интегрированных высокоэффективных системах отопления и водоснабжения горячей водой индивидуальных домов.

ISBN 978-5-91327-576-9

(C) Торопов А.Л., 2019

(С) ИД «Академия Естествознания»

(C) АНО «Академия Естествознания» 


\section{ОГЛАВЛЕНИЕ}

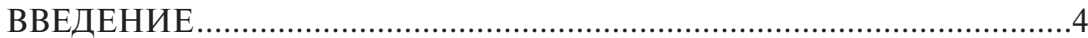

Глава 1. ТЕПЛОВЫЕ АККУМУЛЯТОРЫ ............................................10

1.1. Принцип работы и схемы подключения тепловых аккумуляторов ......................................................... 10

1.2. Назначение и классификация тепловых аккумуляторов..........15

1.3. Энергетические и эксплуатационные показатели тепловых аккумуляторов ........................................................19

Глава 2. БОЙЛЕРЫ КОСВЕННОГО НАГРЕВА..................................28

2.1. Конструкции бойлеров косвенного нагрева ………….............28

2.2. Расчет характеристик бойлеров косвенного нагрева ................30

2.3. Подбор параметров бойлера косвенного нагрева

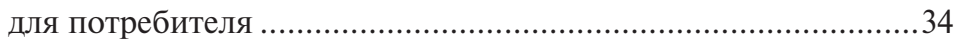

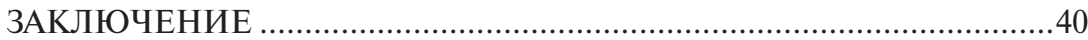

СПИСОК ИСПОЛЬЗОВАННОЙ ЛИТЕРАТУРЫ .................................43 


\section{ВВЕДЕНИЕ}

Создание комфортной среды обитания человека - цель, стоящая перед человечеством на протяжении всего его существования. А правильный, во всех смыслах, температурный режим в индивидуальных домах и квартирах, одна из главных составных задач при достижении этой цели. Всегда есть и обратная сторона любого вопроса - это цена его решения. Затраты на отопление и подготовку горячей воды в индивидуальном хозяйстве составляют значительную долю в бюджете каждой семьи и оптимизация их важна для каждого.

В энергетических задачах, оптимизация затрат всегда связана со стремлением уравнять требуемое количество энергии для создания комфортных условий к оплаченной. Между тем, все мы прекрасно понимаем, что если в канализацию сливается горячая вода, из ванны или душа сливается горячая вода, из трубы котлов идет горячий дым, то это означает, что часть энергии (денег) выбрасывается. При покупке котлов специалисты подбирают оборудование по максимальным значениям. Существующие методики подбора техники основаны на работе оборудования при максимально возможных климатических условиях. С одной стороны, это правильно, с другой, подбор котла, обеспечивающего отопление дома при внешней температуре $-35^{\circ} \mathrm{C}$, приводит к тому, что $99 \%$ времени работы он сильно недогружен и работает с низкой эффективностью. Если спросить у Заказчика, что вы выбираете? Купить котел, обеспечивающий $20^{\circ} \mathrm{C}$ тепла в помещении при $-35^{\circ} \mathrm{C}$, как положено по нормам, не смотря на то, что, к примеру, в Москве такая температура бывает только один раз в 20 лет. Или купить котел на $20 \%$ дешевле и потратить на оплату топлива за время всей жизни котла (10 лет) на 200000 рублей меньше, при условии, что в день, когда (предположительно раз в 20 лет) за окнами будет $-35^{\circ} \mathrm{C}$, при условии, что у вас в доме будет не положенные 20 , а $17^{\circ} \mathrm{C}$. Думаем, большинство Заказчиков примут именно второй вариант.

Современные методы оптимизации инженерного оборудования способны предложить и более эффективный вариант: купить котел еще дешевле и меньшей стоимости и поставить дополнительное устройство, тепловой аккумулятор, который способен аккумулировать тепло в периоды малого потребления энергии и выдавать тепло в периоды максимальной нагрузки. Это и есть путь к высокоэффективным энергетическим системам. 
Повышение эффективности теплогенерирующих установок за счет утилизации теплоты, использования энергии возобновляемых источников, ее аккумулирование и последующее использование в системах отопления и ГВС в моменты «пиковой нагрузки», является актуальной задачей, стоящей перед наукой и промышленными предприятиями.

Аккумуляцией (аккумулированием) тепловой энергии или аккумуляцией теплоты называется процесс накопления тепловой энергии в период ее наибольшего поступления для последующего использования, когда в этом возникнет необходимость. Накопление энергии называется - зарядкой, ее использование - разрядкой.

Использованием данного процесса на практике человечество занимается с незапамятных времен. Классическая русская кирпичная печь отличный пример такого применения. Кроме приготовления пищи, такая печь еще и обогревала помещение. Вес русской печи более трех тонн. Кирпич при нагреве аккумулирует тепловую энергию, а потом, в течение нескольких часов, охлаждаясь, отдает энергию в помещение. Продолжение этой идеи в наше время - использование твердотопливного котла и теплового аккумулятора.

Проблема твердотопливных бытовых котлов в том, что топливо необходимо подкладывать постоянно. Одной загрузки дров хватает на пару часов, в лучшем случае, и, при низкой температуре зимой, приходится подкладывать топливо часто. Ночью это трудно и использование теплового аккумулятора позволит решить проблему поддержания температуры продолжительное время.

Тепловые аккумуляторы позволяют оптимизировать энергопотребление. Можно выбрать режим работы энергетической установки (котел) при максимальном КПД ее работы. В большинстве случаев, это режимы с избытком энергии, который можно направить на зарядку теплового аккумулятора. При отключенном котле, обогрев помещения будет происходить от заряженного аккумулятора. Тоже происходит при наличии устройств возобновляемых источников энергии, например, солнечных коллекторов. Летом, Солнце восходит в рано утром, а потребление тепловой энергии, для ГВС начинается обычно в 7-8 утра. Тепловая солнечная энергия раннего утра может быть заряжена в тепловом аккумуляторе и использована по мере необходимости в более позднее время. Для реализации использования солнечной тепловой энергии в течение всего светового дня можно использовать солнечные коллекторы, конструкции и принцип работы которых описаны в первой части учебного пособия [1].

На производственных предприятиях, тепловые аккумуляторы можно использовать для утилизации энергии технологических процессов, 
сточных вод, температуры дымовых газов. Если на предприятии или в индивидуальном хозяйстве установлены счетчики электроэнергии с дневным и ночным тарифом, то зарядка теплового аккумулятора ночью с дневной разрядкой позволит экономить значительные денежные суммы.

Тепловой аккумулятор (ТА) - устройство для накопления тепла с целью его дальнейшего использования [2].

Тепловой аккумулятор позволяет снизить энергозатраты на отопление и горячее водоснабжение, увеличить ресурс работы оборудования и эффективность системы отопления.

На рис. 1 показаны некоторые типы тепловых аккумуляторов.

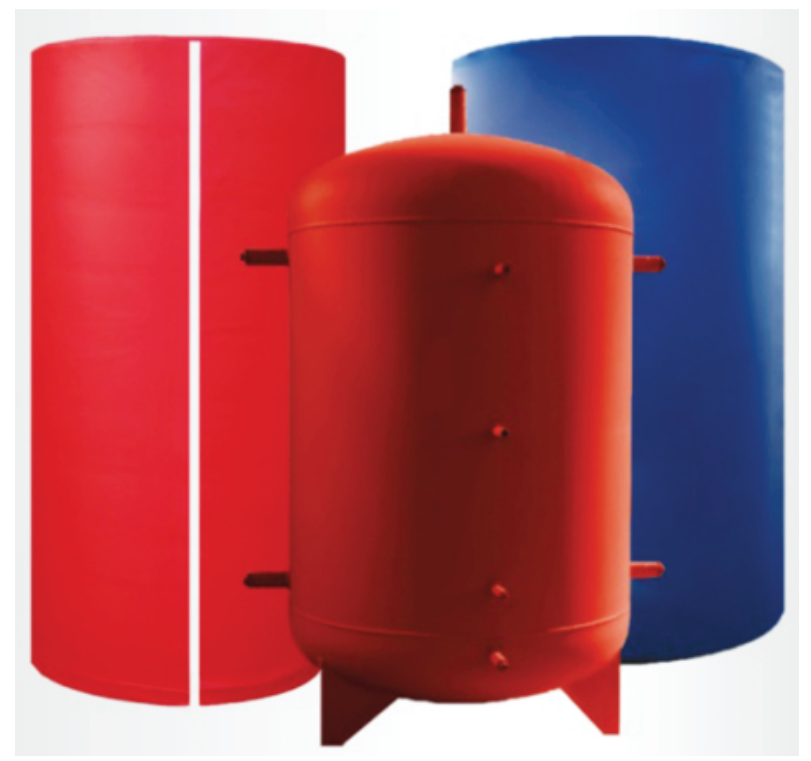

Рис. 1. Тепловые аккумуляторы

TA - устройство для аккумулирования тепловой энергии, основанное на использовании физического или химического процесса, связанного с поглощением и выделением теплоты.

Тепловые аккумуляторы применяются в разных отраслях народного хозяйства - в атомных электростанциях, сельском хозяйстве, металлургии.

Данное учебное пособие посвящено использованию ТА в индивидуальных и децентрализированных (автономных) системах отопления и горячего водоснабжения. 
Практически в $99 \%$ случаев в России используются низкотемпературные приборы отопления - радиаторы различных типов, конвекторы, «теплые пол», воздушно-водяные вентиляторы. Все относятся к оборудованию с температурой теплоносителя от 30 до $100^{\circ} \mathrm{C}$. Нижний порог обусловлен минимальной комфортной температурой, а верхний - максимальной температурой воды, как наиболее часто используемого теплоносителя для отопления и ГВС.

Вторым ограничительным моментом предмета изучения данного учебного пособия, является продолжительность цикла работы теплового аккумулятора. В нем рассматриваются устройства кратковременного использования, связанные с циклом солнечного светового дня и ночи и суточной жизнедеятельностью человека, то есть продолжительностью работы от нескольких часов до суток. Максимальный рассматриваемый цикл применения оборудования равен неделе.

Бойлеры косвенного нагрева (БКН), устройство очень похожее на тепловой аккумулятор и фактически является тепловым аккумулятором, но есть некоторые особенности.

Бойлер (англ. boiler - котёл) - водонагревающее устройство в системе снабжения теплом и горячей водой. Как правило, при этом, в русском языке «бойлер» предполагается, как нечто отличное от котла. В быту, бойлером часто называют любой водонагреватель: бойлер косвенного нагрева, электроводонагреватель и даже газовую колонку.

Можно сказать, что название «БОЙЛЕР», в русском языке, приобрело смысл устройства для нагрева именно горячей воды, а не котла системы отопления.

Прямой нагрев - тепло от сжигания газа, твердого топлива, передается нагреваемому телу или среде, посредством теплопроводности, конвекции или излучения.

Косвенный нагрев - тело или среда нагревается под действием промежуточного нагревательного элемента. К примеру, первоначально, огонь нагревает трубку, по которой течет вода, затем нагретая трубка передает тепло нагреваемой среде. То есть, фактически, получается двухэтапный (двухступенчатый) процесс подогрева.

В нашем случае (БКН), для подготовки горячей воды используется тепло в трубах системы отопления. Они нагревают в емкости воду, которая используется, как горячая вода бытового и промышленного потребления.

Общее в тепловых аккумуляторах и бойлерах косвенного нагрева то, что они аккумулируют тепловую энергию, полученного от внешнего источника. Разница в том, то тепловые аккумуляторы выдают эту энергию в систему отопления, в случае, когда традиционной источник энергии 


\section{A.A. Торопов}

отключен. В бойлерах косвенного нагрева, задача более узкая и специализированная - накопленная энергия тепла используется для подготовки именно горячей воды. В тепловых аккумуляторах материалом, аккумулирующим тепловую энергию, может быть любой материал (вода, камень, парафин, и так далее). В бойлерах косвенного нагрева, этим материалом может быть только вода.

Можно сказать, что бойлер косвенного нагрева, это специализированное применение теплового аккумулятора для подготовки воды в системе горячего водоснабжения конечного потребителя.

На рис. 2 показаны некоторые типы бойлеров косвенного нагрева.

Есть еще одна особенность применения БКН. В системах подготовки горячей воды для индивидуального потребления используют двухконтурные настенные котлы. Первый контур, это контур отопления. Второй контур - горячего водоснабжения. Подготовка горячей воды в таких котлах - вторичный режим. Система работает на отопление, как на основной режим постоянного использования. Если вам потребуется горячая вода, то котел переключается на производство горячей воды. Но это переключение продолжается несколько секунд. Кроме того, данные котлы обеспечивают потребление горячей водой только одну-две точки разбора. Например, кухонный кран и душевую. Если одновременно пользоваться горячей водой и душевой и кухонным краном, то трудно выставить комфортную температуру потребления горячей вода, поскольку горячую воду потребляют разные люди по своему усмотрению. При одновременном потреблении температура падает и это постоянно вызывает дискомфорт. То есть настенные двухконтурные котлы не могут обеспечить комфортное одновременное использование горячей водой несколько точек разбора. Если применить в системе бойлер косвенного нагрева, то можно решить этот вопрос. БКН, в данном случае, выступает как гаситель пиковой нагрузки потребления горячей воды.

Бойлеры косвенного нагрева, динамичные устройства, способные восстанавливаться от пикового потребления горячей воды за несколько десятков минут. Если в системе горячего водоснабжения индивидуального дома используется электрический водонагреватель, то после приема полноценного по времени душа даже одним человеком, требуется время восстановления температуры воды для следующего использования, равное часу и более. При использовании БКН, это время 10-20 минут.

Тепловые аккумуляторы более консервативные технические устройства. Цикл их полной зарядки и разрядки, как правило, оставляет несколько (более 5 часов), даже для самых оперативных систем с дневным циклом работы. 

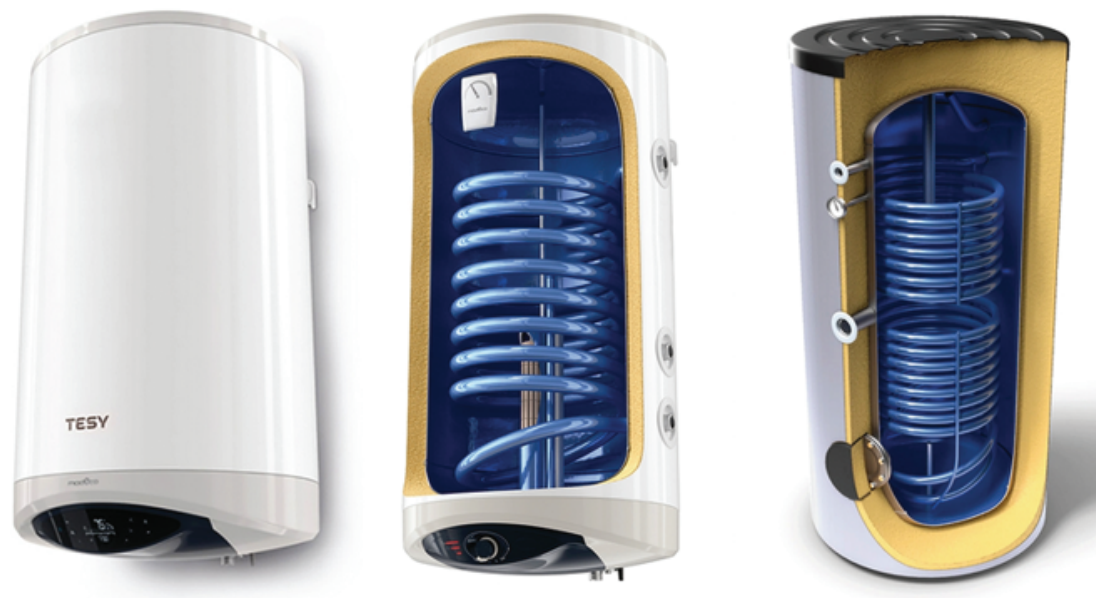

Рис. 2. Внешний вид и разрезы некоторых типов бойлеров косвенного нагрева

Современные тепловые аккумуляторы и бойлеры косвенного нагрева, технические устройства, позволяющие создать высокоэффективные энергосберегающие системы отопления и ГВС, с традиционными углеводородными энергетическими ресурсами и источниками возобновляемой энергии, для индивидуальных, коллективных и коммерческих зданий.

\section{Дитература по разделу Введение}

1. Торопов А.Л. Комбинированные тепловые гелиосистемы. Ч. 1. Тепловые солнечные коллекторы для индивидуальных и децентрализованных систем отопления и горячего водоснабжения: учебное пособие. М.: Издательский дом Академии Естествознания, 2019. - 88 с.

2. СНиП 2.04.01-85. Внутренний водопровод и канализация зданий. 


\section{Гдава 1. ТЕПЯОВЫЕ АККУМУ ЯЯТОРЫ}

\section{1. Принцип работы и схемы подкдючения тепловых аккумуляторов}

Тепловые аккумуляторы состоят из внутреннего бака с размещенным в нем теплоаккумулирующим материалом и теплообменниками контуров зарядки и разрядки, теплоизолирующего материала, внешней декоративной оболочки и соединительных патрубков.

Схема работы простейшего теплового аккумулятора (буферной емкости) представлена на рис. 3.

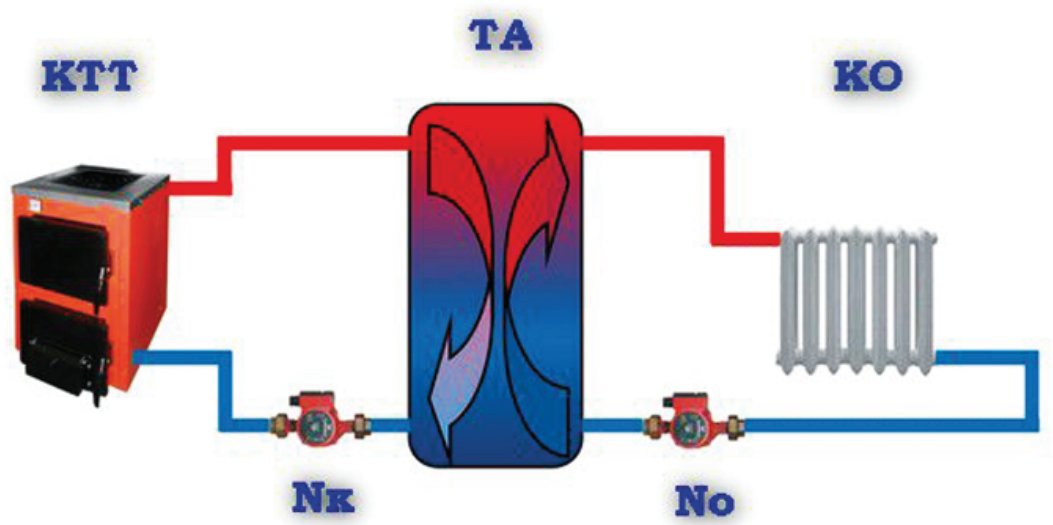

Рис. 3. Схема работы теплового аккумулятора

В левой стороне контур зарядки, в правой стороне контур потребления (разрядки). Движение теплоносителя осуществляется циркуляционными насосами. Источником энергии служит котел водяного отопления. В качестве потребителя тепловой энергии - радиаторы водяного отопления. Данная схема функционирования ТА называется «с прямым подключением контуров», конструкция такого ТА представлена на рис. 4.

Котел, тепловой аккумулятор, трубопроводы обоих контуров, отопительные приборы, все заполнено одним теплоносителем.

Твердотопливный котел производит тепло, которое передается теплоносителю, и по трубопроводу контура зарядки поступает в ТА. Поскольку теплый теплоноситель имеет меньшую плотность, чем холодный, 
большого смешивания теплого теплоносителя с холодным не происходит, и он поступает в контур разрядки к отопительному прибору.

Движение по контуру разрядки осуществляется с помощью циркуляционного насоса. Остывший в отопительном приборе теплоноситель поступает в нижнюю часть ТА и потом, через контур зарядки, в котел. В данной схеме работы, одновременно происходит нагрев отопительных приборов и, постепенно, нагрев самого теплового аккумулятора.

Bсе контуры и элементы системы соединены между собой, следовательно, вся система работает на одном уровне давления.

Конструкция теплового аккумулятора состоит из внутреннего бака, патрубков подсоединительных трубопроводов, теплоизоляционного слоя, внешнего декоративного покрытия. Внутренний бак напорный, избыточное давление в нем порядка 3 бар, как и во всей системе отопления, работающей

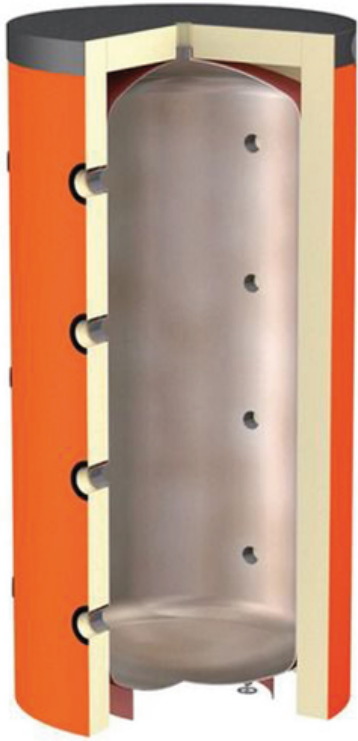

Рис. 4. Тепловой аккумулятор с прямым подключением контуров по данной схеме. Баки изготовлены из нержавеющей стали или из черной стали с антикоррозионным покрытием. Теплоизоляционный слой, покрывающий поверхность бака, выполнен из 10-сантиметрового слоя минеральной ваты, пенопласта или другого теплоизоляционного материала. ТА всегда выполняются в напольном варианте из-за больших размеров и веса.

В работе отопительных систем с ТА данного типа, для более эффективного управления процессом обогрева помещения и зарядки ТА, используют также схему с трехходовым клапаном, представленную на рис. 5. Если установить термическую головку управления трехходового клапана на заданную потребителем температуру, то при достижении значения выше заданного, клапан запирает поступление горячего теплоносителя из ТА в контур разрядки и тогда возникает два новых контура. Котел всю энергию передает в нагрев ТА, а контур разрядки формируется циркуляционным насосом, минуя ТА. При остывании теплоносителя ниже заданной на трехходовом клапане значения температуры, он открывается, и система работает в первоначальном варианте, нагревая и ТА и приборы отопления. 


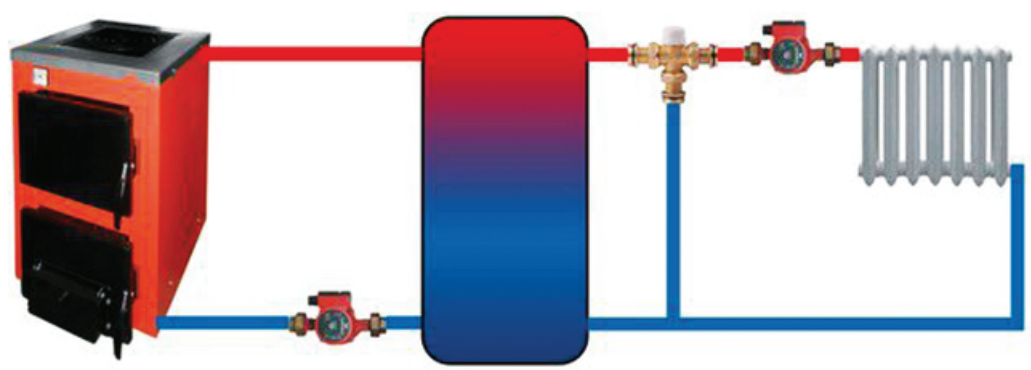

Рис. 5. Тепловой Аккумулятор с прямым подключением контуров и трехходовым клапаном

В случае, если в контуре зарядки и контуре отопительных приборов (разрядки) теплоносители разные, то их надо разделить. Для этого, во внутреннем баке ТА размещается встроенный теплообменник - свитая в спираль часть трубопровода котельного контура зарядки (см. рис. 6).

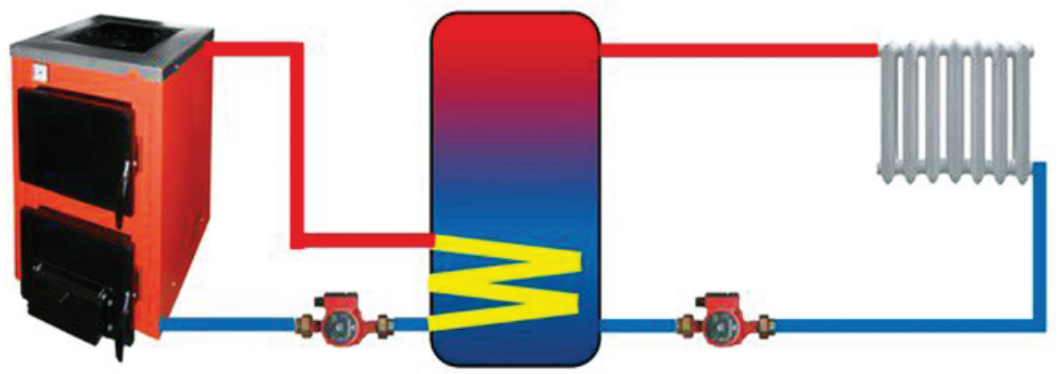

Рис. 6. Схема работы теплового аккумулятора с встроенным теплообменником

При работе ТА данного типа возможно не только различие в теплоносителях контуров, но и его интегрирование в систему коллективного отопления и ГВС с давлением в контуре тепловых приборов до 6 бар, в то время, как в контуре зарядки стандартных котельных агрегатов, максимальное давление составляет до 3 бар. ТА данного типа представлен на рис. 7. В отличие от предыдущего типа ТА, кроме внутреннего спиралеобразного теплообменника, во внутреннем баке установлен еще и магниевый анод. Узел, консервирующий коррозию внутреннего стального бака.

На рис. 8, представлен ТА с двумя внутренними теплообменниками.

В качестве второго контура подключения может быть солнечный коллектор, как источник возобновляемой энергии. Конструкции 
и принцип работы данных приборов описаны в работе [1]. Может быть вариант, когда контур зарядки имеет один внутренний теплообменник, контур разрядки, второй внутренний теплообменник, в баке размещен специальный термоаккумурирующий материал, причем любого агрегатного состояния. Схема работы теплового аккумулятора с прямым подключением контуров и с встроенным внутренним баком для отдельного контура ГВС представлена на рис. 9.

Конструкция теплового аккумулятора может быть с двумя внутренними объемными баками и встроенными теплообменниками, один из

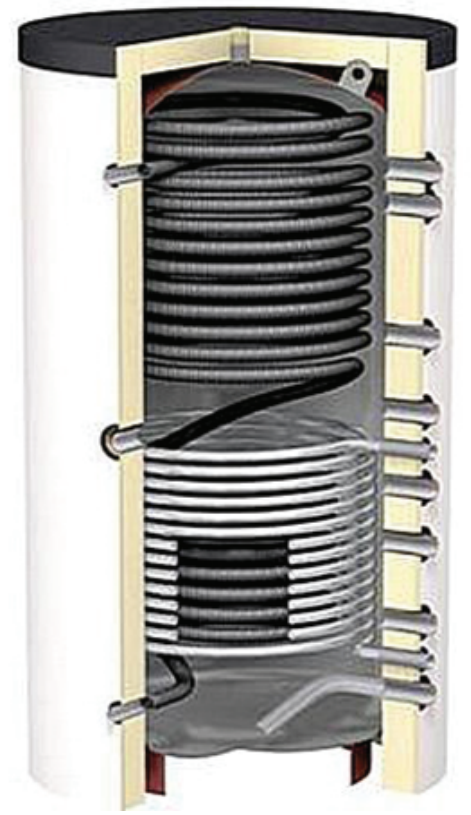

Рис. 8. Тепловой аккумулятор с двумя теплообменниками

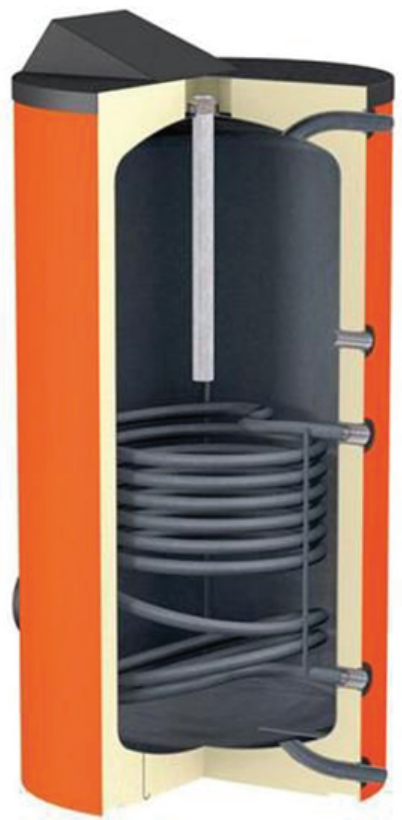

Рис. 7. Тепловой аккумулятор с встроенным теплообменником и магниевым анодом

вариантов такого ТА представлен на рис. 10 .

В данном разделе показаны некоторые типовые TA. Существуют и другие конструкции ТА и схемы их подсоединения. Все они обусловлены требованиями к тепловым носителям, используемым в узлах систем отопления и ГВС, рабочими давлениями в контурах циркуляции, расходными характеристиками узлов, алгоритмом функционирования. 


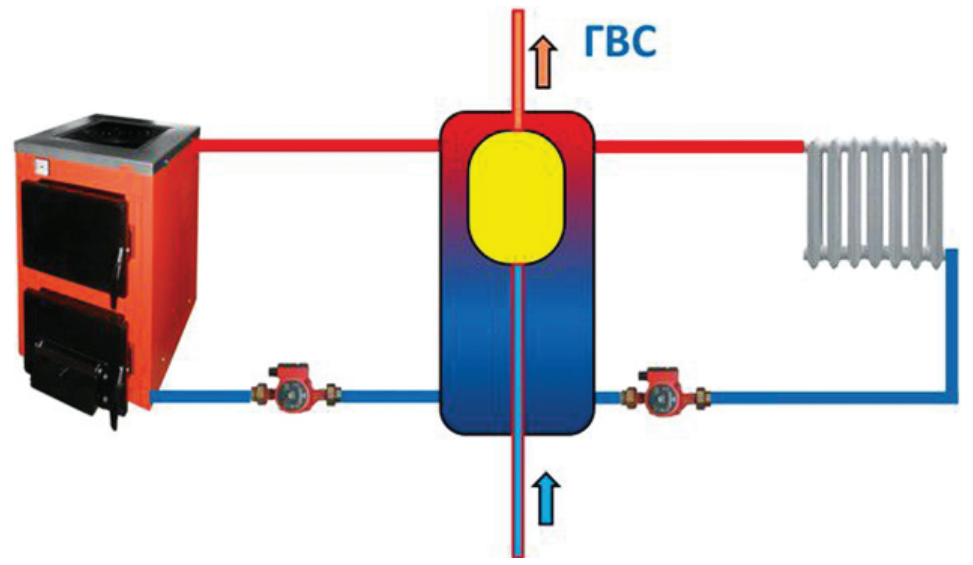

Рис. 9. Схема подключения теплового аккумулятора с внутренним баком ГВС

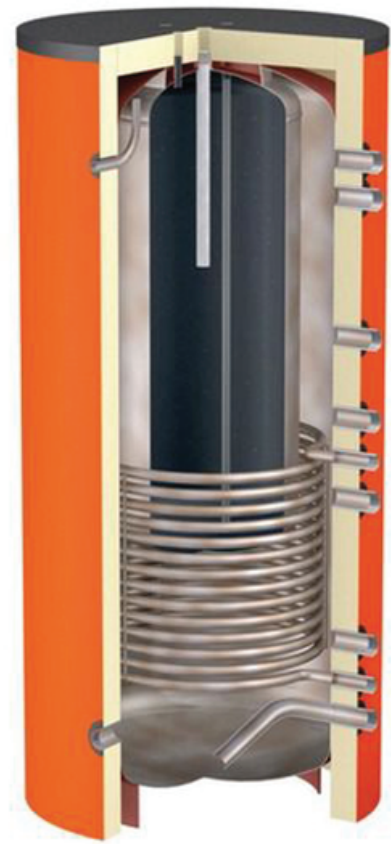

Рис. 10. Тепловой аккумулятор с двумя внутренними баками и встроенным спиральным теплообменником 


\section{2. Назначение и классификация тепловых аккумуляторов}

Работа теплового аккумулятора основана на способности веществ запасать энергию при нагревании и отдавать при остывании. Вещества, используемые для накопления тепловой энергии, называются теплоаккумулирующими материалами (ТАМ). Наиболее часто применяемым материалом, способным эффективно аккумулировать теплоту с последующей отдачей, является вода. Ее очень легко нагреть в трубопроводе, она легко отдает тепло. Вода - экологически чистый материал, обладающий высокой теплоемкостью.

Теплоёмкость - количество теплоты, поглощаемой (выделяемой) телом в процессе нагревания (остывания) на 1 Кельвин. Размерность, Дж/К,

Уде́льная теплоёмкость - это отношение теплоёмкости к массе, теплоёмкость единичной массы вещества (разная для различных веществ); физическая величина, численно равная количеству теплоты, которое необходимо передать единичной массе данного вещества для того, чтобы его температура изменилась на единицу.

В Международной системе единиц (СИ) удельная теплоёмкость измеряется в джоулях на килограмм на Кельвин, Дж/(кг·К).

По типу процесса аккумулирования энергии в тепловых аккумуляторах различают [2-4]:

- тепловое аккумулирование энергии твердыми и жидкими телами за счет изменения температуры вещества - однофазная, емкостная аккумуляция;

- тепловое аккумулирование энергии посредством использования теплоты фазового перехода;

- термохимическое аккумулирование тепловой энергии.

Первый тип данной классификации, тепловые емкостные аккумуляторы (TEA), нашли широкое применение в народном хозяйстве. В них используются различные дешевые теплоаккумулирующие материалы, например, вода. Агрегатное состояние ТАМ в них не меняется во всем рабочем диапазоне. Зарядка и разрядка характеризуется исключительно переменной температурой. Данный тип ТА имеет низкую эффективность. Низкая теплоемкость ТАМ данного типа компенсируется большим объемом устройства. Однако, большие размеры TEA, необходимые для обеспечения разрядки в течение 5-7 часов для помещений более 100 квадратных метров, приводят к трудностям монтажа и эксплуатации этих систем. Стоимость таких устройств изза большого размера, также достаточно велика. 
В качестве ТАМ для аккумуляторов данного типа применяют широко распространенные и дешевые жидкие и твердые материалы и их комбинации (вода, камень щебень).

Для лучшего восприятия требуемых объемов теплового аккумулятора, рассмотрим пример.

Дом с отапливаемой площадью 100 квадратных метров. Тепловые потери составляют 5 киловатт в час.

Если требуется поддерживать температуру за счет теплового аккумулятора в течение 7 часов, то его мощность должна быть равна 35 киловатт.

Используем в качестве теплоаккумулирующего материала воду. Тогда масса М ТАМ определяется по формуле:

$$
\begin{gathered}
M=\frac{Q}{\left(T_{2}-T_{1}\right) \cdot C y}= \\
=35000 \cdot \frac{3600}{(75-35) \cdot 4182}=753 \text { литра, }
\end{gathered}
$$

где $C y$ - удельная теплоемкость воды, 4182 Дж/(кг·К);

$T_{2}$ - максимальная температура, $75^{\circ} \mathrm{C}$;

$T_{1}$ - минимальная температура, $35^{\circ} \mathrm{C}$;

$Q$ - мощность аккумулятора. 35000 Вт.

Введем понятие эффективный рабочий диапазон температур ТА.

Нижний уровень определяется санитарными нормами в жилых и офисных помешениях, он равен $20^{\circ} \mathrm{C}$. Из массово применяемых отопительных приборов самые низкие требования к температуре в системе отопления имеет «теплый пол». Температура в напорной магистрали должна быть не меньше $35^{\circ} \mathrm{C}$. В радиаторных (98\% российского рынка) системах отопления, минимальная температура в подающих магистралях не должна быть ниже $40-50^{\circ} \mathrm{C}$. Следовательно, нижний предел рабочего диапазона ТА, примем равным $35^{\circ} \mathrm{C}$. Верхний уровень рабочего диапазона также определяется санитарными нормами. Это связано с возможным ожогом кожи при работе радиаторов отопления. Этот порог нагрева батарей определен в $65^{\circ} \mathrm{C}$. Но это батареи, в системе отопления есть другое ограничение. К примеру, все настенные газовые котлы имеют ограничение работы система нагрева теплоносителя в $80^{\circ} \mathrm{C}$. После достижения этого порога, нагрев котла прерывается, чтобы не допустить закипание теплоносителя в котле. В ТА теплоноситель поступает по трубопроводу с некоторым охлаждением. Принимаем верхний уровень рабочего диапазона ТА $75^{\circ} \mathrm{C}$. 
Второй тип устройств данной классификации - аккумуляторы теплоты фазового перехода, общепринятое сокращение (АФП), основан на использовании обратимого процесса фазового перехода плавление затвердевание. В качестве ТАМ для этих устройств, применяются материалы с изменяющимся фазовым состоянием в диапазоне температур эксплуатации системы. Конструкции ТА данного типа более сложные и дорогие, но в них на единицу объема запасается больше энергии, чем для тепловых аккумуляторов первого типа, причем процесс зарядки и разрядки в них происходит в очень узком диапазоне температур.

В зависимости от того, переходит твердое состояние ТАМ в жидкое, или обратно, процесс протекает с поглощением или выделением тепла. Эта теплота называется скрытой теплотой фазового перехода. Она затрачивается на разрушение кристаллической решетки при плавлении и выделяется при кристаллизации.

В связи с тем, что плотности и теплопроводности ТАМ с фазовым переходом в твердом и жидком состоянии отличаются, применяются также схемы с промежуточным теплоносителем (вода), которые осуществляют теплопередачу энергии от источника к ТАМ при зарядка и от ТАМ к потребителю при зарядке. Конструкции таких устройств могут быть разнообразные.

Основными требованиями к ТАМ, являются:

- температура фазового перехода должна соответствовать рабочим параметрам теплоносителя в режимах зарядки и разрядки;

- иметь низкий коэффициент объемного расширения и по возможности меньшую разницу плотностей жидкой и твердой фаз;

- быть химически совместимым с конструкционными материалами ТА;

- иметь стабильность состава и теплофизических свойств на протяжении всего периода эксплуатации;

- быть доступным и иметь низкую стоимость.

Наиболее пригодными для низкотемпературных АФП считаются парафины. Достоинства парафинов:

- большая теплота фазового перехода;

- отсутствие эффекта переохлаждения;

- низкий коэффициент вязкости;

- парафин, в жидком состоянии неполярная жидкость и поэтому не смешивается с полярными, такими как вода и спирт;

- низкая электропроводность;

- долговечен и стабилен при циклическом изменении агрегатного состояния;

- температура воспламенения выше $250^{\circ} \mathrm{C}$; 
- стабильность при нагреве до $250^{\circ} \mathrm{C}$;

- не кипит, нет опасности возникновения высокого давления пара даже при высоких рабочих температурах;

- экологически безвреден;

- не токсичен, не вреден для здоровья;

- являются коррозионно устойчивыми материалами.

Плотность термических парафинов в жидком состоянии колеблется от 750 до 850 кг/м³ и в твердом от 800 до 900 кг $/ \mathrm{M}^{3}$. Перечисленные свойства парафина делают его идеальным материалом для различных приложений, связанных с низкотемпературной аккумуляцией теплоты.

Главным и существенным недостатком парафинов - низкий коэффициент теплопроводность в твердой фазе и изменение плотности при фазовом переходе. Данные о теплофизических свойствах ТАМ представлены в [5-6].

Термохимический - третий способ аккумулирования тепловой энергии, основан на использовании обратимых химических реакций и позволяет запасать тепловой энергии на единицу массы больше, чем в первых двух случаях, но сложен в реализации и в конструкциях, применяемых в системах отопления и ГВС, в настоящее время, практически, не применяется.

По интервалу рабочих температур тепловые аккумуляторы систем отопления и ГВС можно разделить на три группы:

- низкотемпературные $-35^{\circ} \mathrm{C}<T<100^{\circ} \mathrm{C}$;

- среднетемпературные $-100^{\circ} \mathrm{C}<T<500^{\circ} \mathrm{C}$;

- высокотемпературные $-T>500^{\circ} \mathrm{C}$.

В системах отопления и ГВС, наиболее широкое применение нашли низкотемпературные ТА. Это обусловлено тем, что диапазоны рабочих температур, которые возникают в этих системах, конструкционные и технологические материалы из которых сделаны узлы и элементы этих систем, все это рассчитано, в подавляющем большинстве, на диапазон эксплуатационных температур до $120^{\circ} \mathrm{C}$.

Средне- и высокотемпературные тепловые аккумуляторы пока не нашли широкого применения в промышленности. Применение среднетемпературных тепловых аккумуляторов связано, в основном, с энергетическими установками и системами утилизации тепла технологических процессов с высокими температурами, а высокотемпературные ТА могут применяться в металлургии.

По временному фактору использования тепловые аккумуляторы различают на:

ш краткосрочного действия (суточные) - цикла работы (зарядка/разрядка) не превышает продолжительности суток; 
долгосрочного действия - продолжительность процесса зарядки и разрядки превышает продолжительность суток (может достигать недельного, месячного и годового периода).

Создание комфортной среды обитания человека связано с его жизненным циклом. Короткий период, это сутки и в сутках есть дневное (активное) время и ночное (пассивное). Продолжительность сна составляет около 7-8 часов. Именно этот период времени можно рассматривать, как минимальный период работы аккумулятора тепла. Человек в это время не может контролировать оборудование систем отопления и ГВС, к примеру, закладывать топливо в твердотопливный котел индивидуального дома. ТА предназначен для решения этой проблемы. Если рассмотреть цикл потребления горячей воды населением, то он также имеет суточный характер потребления. График потребления ГВС одного из многоквартирных домов представлен на рис. 11.

$\mathrm{m}^{3} / 4$

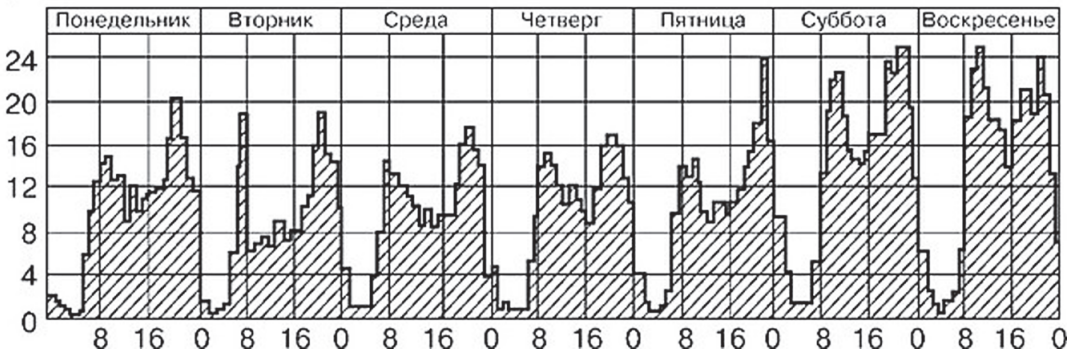

Рис. 11. График потребления горячей воды многоквартирного дома

Тепловые аккумуляторы для систем горячего водоснабжения и отопления индивидуальных домов и децентрализованных систем, ориентированы на краткосрочное действие. Системы поддержания температуры в помещении при отсутствии обитателей могут быть рассчитаны на недельный цикл.

В данном учебном пособии рассмотрены именно случаи использования низкотемпературных, кратковременного использования емкостных и фазовопереходных тепловых аккумуляторов.

\section{3. Энергетические и эксплуатационные показатели тепловых аккумудяторов}

Энергетические и эксплуатационные показатели ТА позволяют потребителю правильно выбрать технические устройства. 
К основным характеристикам ТА относятся:

- удельная мощность;

- мощность ТА;

- удельная стоимость накопителя энергии;

- время заряда-разряда;

- срок службы;

- КПД;

- саморазряд;

- безопасность;

- простота обслуживания.

Теплоаккумуляционная способность или мощность, которую можно накопить в аккумуляторе теплоты емкостного типа, находится из формулы:

$$
Q=m \cdot C p \cdot\left(T_{\mathrm{K}}-T_{\mathrm{H}}\right),
$$

где $m$ - масса теплоаккумулирующего ТАМ, кг;

$C p$ - удельная изобарная теплоемкость ТАМ, Дж/(кг $\mathrm{K})$;

$T_{\text {к }}$ и $T_{\text {н }}-$ значения начальной и конечной температуры ТАМ;

$Q$ - мощность ТА, Дж (для перевода в киловатты надо разделить на $\left.3,6 \cdot 10^{6}\right)$.

Темплоемкость некоторых материалов, которые могут быть использованы в однофазных (емкостных) ТА представлены в табл. 1.

Таблица 1 Удельная теплоемкость, плотность, объемная теплоемкость некоторых ТАМ

\begin{tabular}{|c|c|c|c|}
\hline Материал & $\begin{array}{l}\text { Удельная теплоем- } \\
\text { кость, кДж/(кг·К) } \\
\end{array}$ & $\begin{array}{c}\text { Плотность, } \\
\text { кг } / \mathrm{M}^{3}\end{array}$ & $\begin{array}{c}\text { Теплоемкость, } \\
\left.\text { кДж/( } \mathrm{M}^{3} \cdot \mathrm{K}\right) \\
\end{array}$ \\
\hline Вода & 4,19 & 1000 & 4187 \\
\hline Металлоконструкции & 0,46 & 7833 & 3437 \\
\hline Бетон & 1,13 & 2242 & 2375 \\
\hline Кирпич & 0,84 & 2242 & 1750 \\
\hline Магнетит, железная руда & 0,68 & 5125 & 3312 \\
\hline Базальт, каменная порода & 0,82 & 2880 & 2250 \\
\hline Мрамор & 0,86 & 2880 & 2375 \\
\hline
\end{tabular}

Рассмотрим ТА с объемом кубический метр и диапазон температуры зарядки от 35 до $75^{\circ} \mathrm{C}$. 
Тогда, при равных объемах аккумуляторов, при использовании в качестве ТАМ воды, мощность ТА будет равна 46,5 кВт, металла - 38,2 кВт, бетона - 26,4 кВт, кирпича - 19,4 кВт, мрамор - 26,4 кВт.

Расчет показывает, что для емкостных ТА, наилучшим аккумулирующим материалом является вода. Любые комбинации ТАМ (вода + твердый материал) дают результат мощности хуже, чем однородная вода.

В случае, если в тепловом аккумуляторе используются материалы с фазовым переходом, то мощность ТА определяется по формуле 3.

$$
Q_{\phi}=m \cdot\left(C_{\mathrm{T}} \cdot\left(T_{\phi}-T_{\mathrm{H}}\right)+R_{\phi}+C_{*} \cdot\left(T_{\mathrm{K}}-T_{\phi}\right)\right),
$$

где $Q_{\phi}-$ мощность ТА с фазовым переходом, Дж;

$m$ - масса ТАМ, кг;

$C_{\text {т }}$ и $C_{\text {ж }}$ - удельные теплоемкости ТАМ в твердом и жидком состоянии, Дж/(кг·град.);

$T_{\text {н }}, T_{\phi}, T_{\text {к }}-$ температуры ТАМ начальная, фазового перехода, конечная, град.;

$R_{\phi}-$ удельная теплота фазового перехода, Дж/кг.

Теплофизические свойства некоторых парафинов представлены в табл. 2.

Та блица 2

Термодинамические свойства восков (парафинов) [7]

\begin{tabular}{|l|c|c|}
\hline \multicolumn{1}{|c|}{ Наименование вещества } & $\begin{array}{c}\text { Температура } \\
\text { плавления, }{ }^{\circ} \mathrm{C}\end{array}$ & $\begin{array}{c}\text { Удельная теплота фазо- } \\
\text { вого перехода, кДж/кг }\end{array}$ \\
\hline Карнаубский воск & $62,9-72,0$ & 115,3 \\
\hline Канделийский воск & $60,0-68,0$ & 175,2 \\
\hline Технический воск & $72,6-87,2$ & 146,9 \\
\hline Буроугольный воск & $73,9-89,0$ & 138,8 \\
\hline Торфяной воск & $46,0-69,0$ & 54,0 \\
\hline Торфяной воск модифицированный & $66,0-77,0$ & 59,6 \\
\hline Торфяной воск обессмоленный & $77,0-82,0$ & 75,7 \\
\hline Озокерит & $56,6-76$ & 140,6 \\
\hline Вощина & $46,0-54,0$ & 100,4 \\
\hline Полиэтиленовый воск & $103,8-109,5$ & 161,0 \\
\hline
\end{tabular}




\section{A.A. Торопов}

Теплофихические характеристики парафинов в разном фазовом состоянии различны. Если взять в качестве примера ТАМ парафин с температурой плавления $55^{\circ} \mathrm{C}$ и удельной теплотой фазового перехода, равной 150 кДж/кг, объем ТА один кубический метр, диапазон изменения температур зарядки $35-75^{\circ} \mathrm{C}$, плотность в твердом состоянии $900 \mathrm{\kappa г} / \mathrm{M}^{3}$, а в жидком $830 \mathrm{kг} / \mathrm{M}^{3}$, удельную теплоемкость 3000 Дж/(кг·град), то мощность, определенная по формуле (3) будет равна 67,5 кВт. Что на $45 \%$ больше, чем, если ТАМ - вода. Соответственно, если использовать комбинированный вариант ТАМ вода и капсулы или трубки из парафина, в равном соотношении, то мощность этого комбинированного варианта ТА будет на 22,5\% выше, чем при применении воды в качестве ТАМ.

Необходимо отметить также, что при использовании радиаторов в качестве приборов водяного отопления, а это основной способ отопления в России, диапазон эффективной температуры использования ТА сужается. Редко, когда температура радиаторов выше $65^{\circ} \mathrm{C}$, а при нижнем значении в $35^{\circ} \mathrm{C}$ радиаторы практически не греют. По нормам, температура ГВС должна быть около $55^{\circ} \mathrm{C}$. Поэтому, реально эффективный диапазон температур радиаторного использования ТА $45-65^{\circ} \mathrm{C}$. Если рассматривать именно этот диапазон изменения рабочих температур ТА, то мощность водяного ТАМ при объеме кубический метр, составляет 23 кВт, а парафинового, 52 кВт. Разница в 2,26 раза, а это уже очень большое отличие.

Таблица 3

Термофизические характеристики кристаллогидратов

\begin{tabular}{|c|c|c|c|c|c|c|}
\hline \multirow[b]{2}{*}{ Материал } & \multicolumn{4}{|c|}{ Чистая соль } & \multicolumn{2}{|c|}{ Рабочая } \\
\hline & $T_{\text {пл }},{ }^{\circ} \mathrm{C}$ & $Q_{\text {пл }}, \mathrm{kДж/кг}$ & $\begin{array}{c}\rho_{\text {тв }} \cdot 10^{3}, \\
\text { КГ } / M^{3}\end{array}$ & $\begin{array}{l}\rho_{\text {世 }} \cdot 10^{3}, \\
\mathrm{K \Gamma} / \mathrm{M}^{3}\end{array}$ & TAM, $\%$ & Вода, \% \\
\hline $\mathrm{CaCl} \cdot 6 \mathrm{H}_{2} \mathrm{O}$ & 29,7 & 170 & 1,712 & 1,52 & & \\
\hline $\mathrm{Na}_{2} \mathrm{SO}_{4} \cdot 10 \mathrm{H}_{2} \mathrm{O}$ & 32,4 & 251 & 1,46 & 1,48 & 68,2 & 31,8 \\
\hline $\mathrm{Na}_{2} \mathrm{~S}_{2} \mathrm{O}_{3} \cdot 5 \mathrm{H}_{2} \mathrm{O}$ & 48 & 201 & 1,6 & & & \\
\hline $\mathrm{CH}_{3} \mathrm{COONa} \cdot 3 \mathrm{H}_{2} \mathrm{O}$ & 58,2 & 260 & 1,45 & - & $90-95$ & $10-5$ \\
\hline $\mathrm{Ba}(\mathrm{OH})_{2} \cdot 8 \mathrm{H}_{2} \mathrm{O}$ & 78 & 301 & 2,18 & - & 74-94 & $25-6$ \\
\hline $\mathrm{MgCl}_{2} \cdot 6 \mathrm{H}_{2} \mathrm{O}$ & 116 & 165 & 1,57 & - & - & - \\
\hline
\end{tabular}


В низкотемпературных ТА также используют в качестве ТАМ, кристаллогидраты. Теплофизические характеристики некоторых из них представлены в табл. 3.

К важному недостатку данных ТАМ можно отнести их повышенную коррозионную активность, к преимуществам - более высокие показатели удельные мощностные характеристики.

Удельная мощность ТА определяется отношением мощности рассчитанной по формулам (2), (3) на объем ТАМ. К примеру, в рассмотренном выше случае с мощностью аккумулятора объемом кубический метр с водой и парафином, удельная мощность водяного ТАМ в диапазоне температур $20^{\circ} \mathrm{C}$ будет $23 \mathrm{kBт} / \mathrm{M}^{3}$ или $23 \mathrm{Baт} /$ дм$^{3}$, а парафинового, $52 \mathrm{BT} /$ дм $^{3}$. Очень важно обращать внимание и сравнивать характеристики при одном диапазоне температур. Удельные мощности могут быть и относительно других мер веса и объема, например килограмм. В наших рассмотренных случаях данные значения будут для водяного ТАМ 23 Вт/кг и для парафиновых ТАМ 58 ВТ/кг, в рассматриваемом диапазоне температур.

Удельная стоимость ТА - относительный показатель стоимости одного килограмма или кубического дециметра. Удобный показатель для прогнозирования затрат, связанных с установкой ТА и сравнения их эффективности.

Допустим, рассматриваемый ранее водяной ТА стоит 30000 рублей и у него показатель удельной мощности 23000 Вт/м³ , тогда на вложенный рубль приходится 0,77 Вт. А при стоимости парафинового ТА 45000 рублей, его удельная стоимость равна 1,16 Вт/руб. Значит, парафиновый экономически более выгоден при равных других показателях.

Простота обслуживания. Некоторые ТА имеют ограниченное количество циклов разрядки и зарядки и ТАМ надо менять после заданного срока эксплуатации. Если вы используете в качестве ТАМ воду или другой теплоноситель, то периодически их нужно менять. Таким образом, существуют периодические эксплуатационные затраты. Важно, чтобы проведение этих операций не было бы сложным и проводилось не часто.

Безопасность эксплуатации ТА связана, в первую очередь, с простотой и периодичностью обслуживания, надежностью и качеством применяемых узлов и экологичностью материалов, составом ТАМ.

\section{Время заряда - разряда, саморазряд ТА.}

Назначение теплового аккумулятора - собрать избыточную тепловую энергию, сохранить ее максимально длительное время и передать ее потребителю.

Сохранение энергии происходит с помощью теплоизоляционного слоя, покрывающего всю поверхность ТА (стенки, крышку, дно). 


\section{A.Л. Торопов}

В табл. 4 представлена теплофизические показатели теплоизоляционных материалов, применяемых для ТА. Теплопроводность теплоизоляции изменяется, в общем случае, в зависимости от температуры в среднем по линейному закону прямолинейно и приближенно подсчитывается по формуле:

$$
\lambda_{t}=\lambda_{0}+a t,
$$

где $\lambda_{0}-$ коэффициент теплопроводности при $0^{\circ} \mathrm{C}$;

$t$ - температура, ${ }^{\circ} \mathrm{C}$;

$a$ - константа, зависящая от природы материала.

Таблица 4

Теплофизические характеристики теплоизоляционных материалов

\begin{tabular}{|c|c|c|c|c|}
\hline Утеплитель & $\begin{array}{c}\text { Теплопрово- } \\
\text { дность, } \\
\text { Вт } /\left(\mathrm{M}^{\circ}{ }^{\circ} \mathrm{C}\right)\end{array}$ & $\begin{array}{c}\text { Плотность, } \\
\text { кг } / \mathrm{M}^{3}\end{array}$ & $\begin{array}{c}\text { Паропрони- } \\
\text { цаемость, } \\
\text { мг } /(\mathbf{M} \cdot \Psi \cdot \text { Па) }\end{array}$ & Горючесть \\
\hline \multirow{4}{*}{ Пенополиуретан } & 0,023 & 32 & \multirow{4}{*}{$0,0-0,05$} & \multirow{4}{*}{ Самозатухающий } \\
\hline & 0,029 & 40 & & \\
\hline & 0,035 & 60 & & \\
\hline & 0,041 & 80 & & \\
\hline \multirow{3}{*}{$\begin{array}{l}\text { Пенополистирол } \\
\text { (пенопласт) }\end{array}$} & 0,038 & 40 & \multirow{3}{*}{$0,013-0,05$} & \multirow{3}{*}{$\begin{array}{l}\text { Г3 и Г4. Сопротив- } \\
\text { ление возгоранию } \\
\text { и самозатухание }\end{array}$} \\
\hline & 0,041 & 100 & & \\
\hline & 0,05 & 150 & & \\
\hline $\begin{array}{l}\text { Экструдирован- } \\
\text { ный пенополи- } \\
\text { стирол }\end{array}$ & 0,031 & 33 & 0,013 & $\begin{array}{l}\text { Г1 у марок } \\
\text { с антипеновыми } \\
\text { добавками, другие } \\
\text { Г3 и Г4. Сопротив- } \\
\text { ление возгоранию } \\
\text { и самозатухание }\end{array}$ \\
\hline \multirow{3}{*}{$\begin{array}{l}\text { Минеральная } \\
\text { (базальтовая) } \\
\text { вата }\end{array}$} & 0,048 & 50 & \multirow{3}{*}{$0,49-0,6$} & \multirow{3}{*}{ Огнеупорный } \\
\hline & 0,056 & 100 & & \\
\hline & 0,07 & 200 & & \\
\hline $\begin{array}{l}\text { Стекловолокно } \\
\text { (стекловата) }\end{array}$ & $0,041-0,044$ & $155-200$ & 0,5 & Не горит \\
\hline Пенопласт ПВХ & 0,052 & 125 & 0,023 & $\begin{array}{l}\text { ГЗ и Г4. Сопротив- } \\
\text { ление возгоранию } \\
\text { и самозатухание }\end{array}$ \\
\hline Древесные опилки & $0,07-0,18$ & 230 & - & Пожароопасен \\
\hline
\end{tabular}


Саморазряд теплового аккумулятора обусловлен тем, что если к аккумулятору не поступает энергия, то даже через очень хорошую изоляцию, происходит передача тепла от более теплого тела к более холодному, то есть в окружающую тепловой аккумулятор среду. Теплопотери саморазряда зависят от разности температур окружающей среды и теплоносителя в ТА. Чем больше разница температур, тем быстрее остывает ТА. Значения тепловых потерь при саморазряде должны указываться производителем тепловых аккумуляторов в паспортных технических данных. Считается нормальным, если для кубового аккумулятора, при разности температур в $30^{\circ} \mathrm{C}$, тепловые потери саморазряда составляют 50 Вт/ч. Такие потери обеспечивает слой теплоизоляции в 10 см по всем сторонам ТА.

Время заряда и разряда теплового аккумулятора зависит от подведенной (избыточной) мощности и от тепловых потерь дома.

Для того, чтобы определить время разряда нужно разделить накопленную мощность на теплопотери обслуживаемого помещения при отоплении. К примеру, накопленная мощность составляет $52 \mathrm{kBт}$, а теплопотери -6 кВт/ч. Тогда время разряда составляет 8,7 часа. Соответственно и при зарядке теплового аккумулятора, если избыточная мощность составляет $10 \mathrm{kBT} / ч$, то зарядится этот аккумулятор из начального состояния за 5,2 часа.

КПД тепловых аккумуляторов зависит от нескольких главных параметров, среди которых первое место занимает общее термическое сопротивление изоляции ТА.

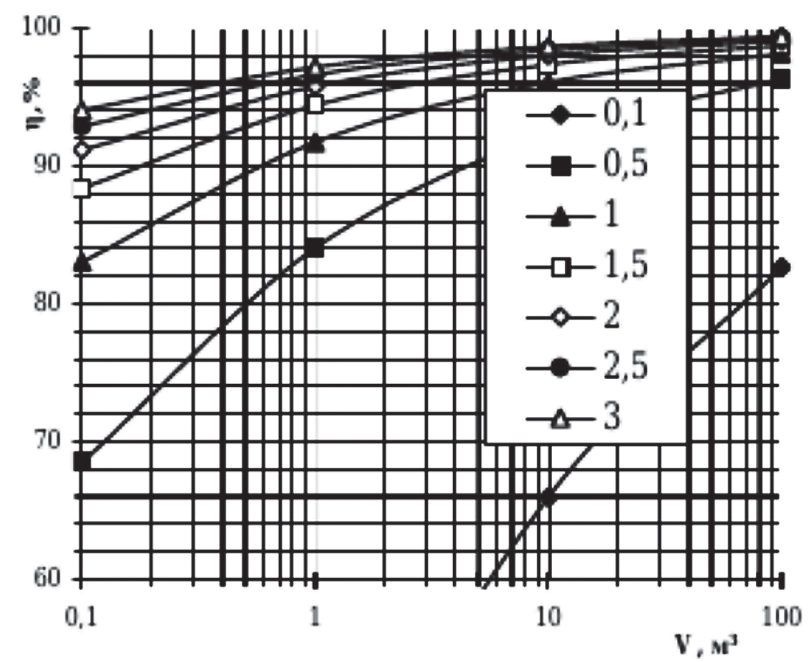

Рис. 12. Графики изменения КПД тепловых аккумуляторов в зависимости от общего термического сопротивления и размеров теплового аккумулятора 
Чем выше этот показатель, тем выше КПД теплового аккумулятора. В работе [8] (рис. 12) представлены графики значения КПД тепловых аккумуляторов с фазовым переходом в зависимости от общего термического сопротивления, времени зарядки и объема ТА.

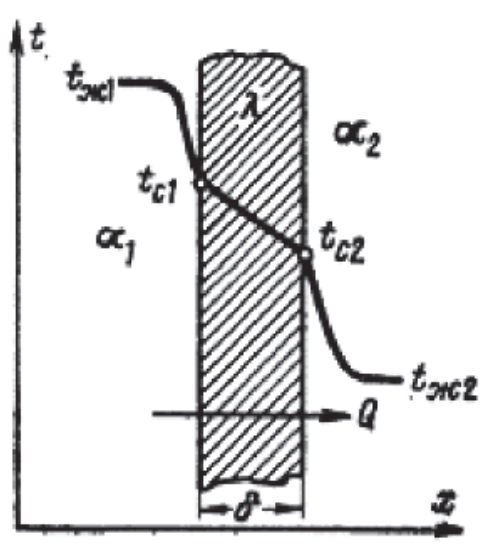

Рис. 13. Схема теплообмена через стенку с учетом теплопередачи и теплоотдачи жидкость-воздух

Из графика видно, что для аккумуляторов с объемом $1 \mathrm{~m}^{3}$, при значении общего термического сопротивления 2, КПД составляет 0,925. Термическое сопротивление, равное 2, соответствует стенке из пенополиуритана с плотностью 80 кг $/ \mathrm{M}^{3}$ и толщиной $8 \mathrm{~cm}$.

Рекомендуем применять толщину теплоизоляционного материала $10 \mathrm{~cm}$, тогда КПД в расчетах низкотемпературных тепловых аккумуляторов можно принимать равным 0,95 .

На рис. 13 представлена схема теплопередачи через стенку теплового аккумулятора и формулы расчета термического сопротивления $R$ с учетом теплоотдачи в окружающий воздух и ТАМ. Общее термическое сопротивление равно сумме частных:

$$
\begin{gathered}
R=R_{\alpha_{1}}+R_{\lambda}+R_{\alpha_{2}} ; \\
R=\frac{1}{k}=\frac{1}{\alpha_{1}}+\frac{\delta}{\lambda}+\frac{1}{\alpha_{2}} ; \\
q=\frac{1}{\frac{1}{\alpha_{1}}+\frac{\delta}{\lambda}+\frac{1}{\alpha_{2}}}=t_{\text {ж}_{1}}-t_{ж_{2}}=k \cdot\left(t_{ж_{1}}-t_{\text {ж }_{2}}\right),
\end{gathered}
$$

где $R \alpha_{2}$ - частное термическое сопротивление теплоотдачи со стороны горячего теплоносителя;

$R \lambda$ - частное термическое сопротивление теплопроводности (стенки);

$R \alpha_{1}$ - частное термическое сопротивление теплооддачи со стороны холодного теплоносителя;

$\delta$ - толщина стенки;

$\lambda$ - удельная теплопроводность изоляционного материала. 
Для условий свободной конвекции воздуха: $\alpha_{1}$ от 5 до 25 Вт/( $\left.{ }^{2} \cdot \mathrm{K}\right)$, воды: $\alpha_{2}$ от 20 до 100 Вт/(м².K). При вынужденной конвекции величины коэффициента теплоотдачи колеблются в пределах: для воздуха: $10-200 \mathrm{Bт} /\left(\mathrm{M}^{2} \cdot \mathrm{K}\right)$, для воды: 50-10 000 Вт/(м²·K).

\section{Питература по главе 1}

1. Торопов А.Л. Комбинированные тепловые гелиосистемы. Ч. 1. Тепловые солнечные коллекторы для индивидуальных и децентрализованных систем отопления и горячего водоснабжения: учебное пособие. М.: Издательский дом Академии Естествознания, 2019. - 88 с.

2. Бекман Г., Гилли П. Тепловое аккумулирование энергии. - М., Мир, 1987.

3. Kreith F., Kreider J.F. Principles of Solar Engineering. - Washington, London, 1978. - $778 \mathrm{p}$.

4. Левенберг В.Д., Ткач М.Р. Гольстрем В.А. Аккумулирование тепла. - К.: «Техника», 1991. - 112 с.

5. Физические величины: справочник / под ред. И.С. Григорьева, Е.3. Мейлихова. - М.: Энергоатомиздат, 1991. - 1232 с.

6. Справочник химика / под ред. Б.П. Никольского. - Л., 1967. $-622 \mathrm{c}$.

7. Боровская Л.В., Шабалина С.Г. Теплоаккумулирующие свойства природных и синтетических восков // Современные наукоемкие технологии. - 2010. - № 4. - С. 98-99.

8. Цимбалюк Ю.В. Методика расчета фазопереходных тепловых аккумуляторов для нефтегазопромысловых объектов // Вестник АГТУ. 2006. - № 6 (35). - C. 98-100. 


\section{ГАава 2. БОЙЛЕРЫ КОСВЕННОГО НАГРЕВА}

\section{1. Конструкции бойлеров косвенного нагрева}

Как было отмечено во Введении, бойлеры косвенного нагрева имеют конструктивные сходства с тепловыми аккумуляторами и отличия.

Общее:

- одинаковое конструктивное решение, состоящее из емкостного бака, теплоизоляции, внутреннего теплообменника, патрубков подключения, магниевого анода, узлов контроля и управления;

- внешний источник энергии в виде нагретого теплоносителя.

Различия:

- в качестве аккумулирующего материала в БКН применяется только вода, качество которой соответствует сантехническим нормам «Питьевая вода», поскольку назначение БКН подготовка воды для ГВС конечного потребителя. В тепловых аккумуляторах может быть любой теплоаккумулирующий материал. Все бойлеры косвенного нагрева - емкостного типа с внутренним теплообменником;

- уровень рабочего и испытательного давлений воды в БКН соответствует требуемому СНИП давлениям систем ГВС, в то время, как тепловые аккумуляторы могут быть безнапорными и иметь атмосферное рабочее давление;

- объем БКН определяется количеством точек разбора горячей воды (душевые, кухни) в помещении и количеством жителей, проживающих в нем. БКН имеют значительно меньший объем, чем ТА;

- БКН имеют меньшую толщину термоизоляции корпуса, поскольку нет необходимости хранить тепловую энергию длительное время. Объем БКН относительно небольшой и температура в нем может быть восстановлена достаточно быстро;

- БКН занимают значительно меньше места, чем ТА, выполняются в настенном и напольном вариантах, размещаются в кухнях, ванных, туалетах. К их внешнему виду, из-за места их размещения, предъявляются более высокие требования.

На рис. 14 представлена схема подключения бойлера косвенного нагрева горячей вода в доме с индивидуальным котлом.

Принцип работы БКН заключается в следующем. Одноконтурный котел отапливает помещение за счет движения теплоносителя 
по отопительному контуру, обеспечиваемого циркуляционным насосом. В котле расположен трехходовой кран, который, под действием управляющего сигнала, имеет два варианта положения. По первому положению трехходового крана движение горячего теплоносителя направляется в контур отопления, по второму, кран перекрывает канал отопительного контура и подает воду в спиралеобразный контур обогрева БКН. Таким образом, котел работает либо на обогрев помещения, либо на обогрев воды в бойлере косвенного нагрева для подготовки горячей воды. БКН емкостного типа. Холодная вода поступает по трубам холодного водоснабжения в емкость БКН и нагревается там трубчатым теплообменником.
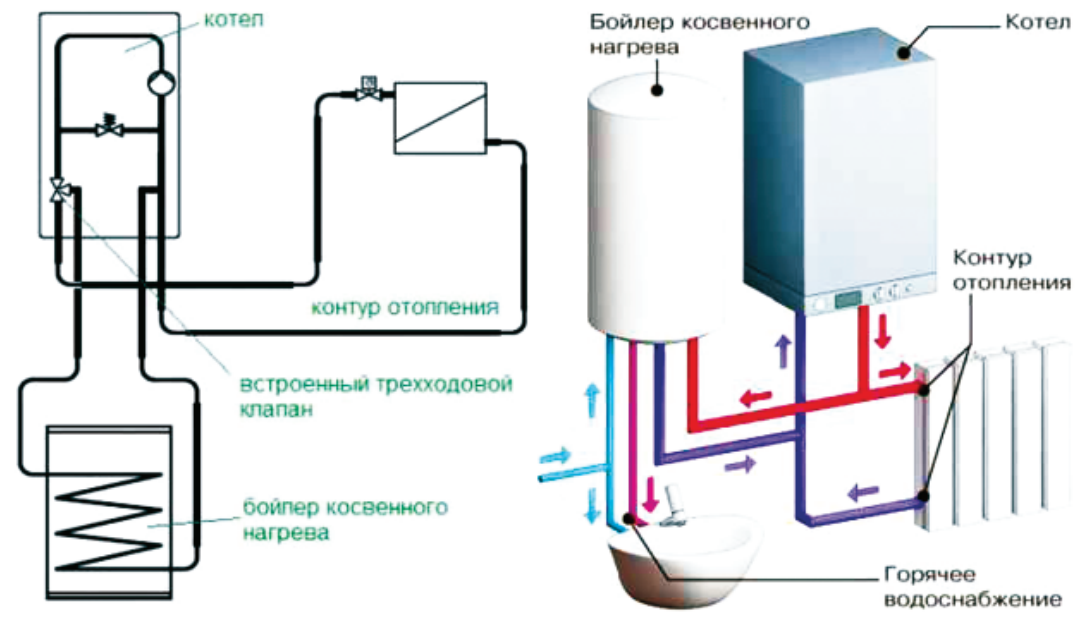

Рис. 14. Схема подключения бойлера косвенного нагрева к отопительному котлу

Управление трехходовым краном производится по значению заданной температуры. По мере расходования горячей воды, температура внутри бака смешивается с холодной водой и несколько охлаждается, но, поскольку работает нагрев от спиралеобразного теплообменника она и подогревается одновременно. При постоянном расходовании горячей воды наступает равновесный момент, в котором температура в БКН больше не опускается. Эта температура определяется мощностью котла расходом воды. 


\section{A.Л. Торопов}

В современных конструкциях БКН есть таймерные устройства, которые можно настроить на требуемый режим подготовки горячей воды при неравномерном использовании. Если у вас БКН предназначен для подготовки горячей воды на даче в выходные дни, то можно настроить программу обогрева, которая подготовит горячую воду к нужному времени, экономя энергию, пока вас нет в помещении. Также есть программы, в виде приложений к смартфону и устройства БКН, способные выбрать режим подогрева ГВС удаленно через интернет.

\section{2. Расчет характеристик бойлеров косвенного нагрева}

Согласно данным представленным в [1] нормы расхода горячей воды на одного человека при температуре $65^{\circ} \mathrm{C}$ составляют 110-130 литров в сутки (для домов, оборудованных ванной размером 1500-1700 мм, умывальникамии, душевыми).

Но это усредненные нормы потребления. В реальности, потребление горячей воды очень индивидуально и зависит не только от количества потребителей и точек разбора, но и от индивидуальных факторов, в том числе, ритма жизни конкретных людей. На рис. 15 представлен один из реальных графиков потребления горячей воды в индивидуальном доме, а на рис. 16 недельное потребление горячей воды в многоквартирном доме.

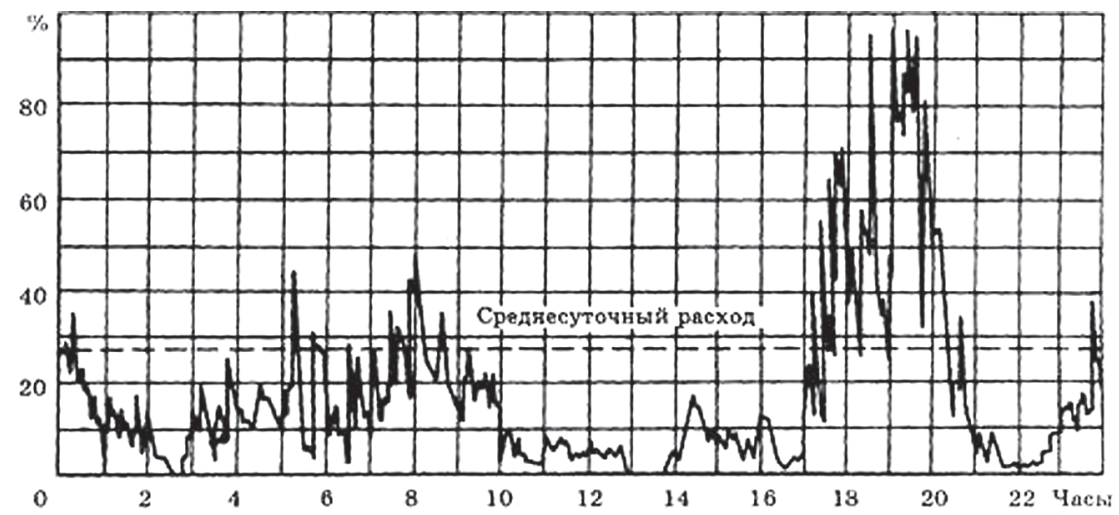

Рис. 15. Один из реальных графиков потребления горячей воды в индивидуальном доме (квартире) 


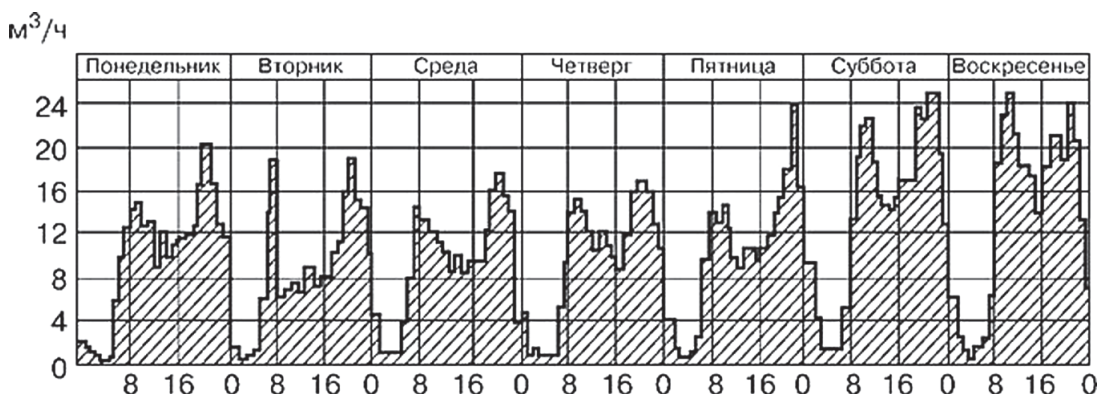

Рис. 16. График варианта недельного потребления горячей воды в многоквартирном доме

Перечислим основные технические характеристики бойлеров косвенного нагрева:

- емкость бойлера;

- емкость теплообменника;

- максимальная мощность теплообменника;

- максимальное давление в теплообменнике;

- потери напора в теплообменнике;

- площадь теплообменника;

- максимальная производительность в проточном режиме, при перепаде температур 25 град.;

- диапазон регулирование температуры в бойлере;

- время нагрева воды в бойлере на разность температур 50 град.;

- максимальное давление воды ГВС;

- время остывания воды в БКН без ее потребления.

Объем (емкость) БКН. Следует различать реальную расчетную емкость БКН и декларированную в каталогах и рекламных материалах. В промышленных БКН, в большинстве случаев, указывается реальная емкость БКН. В бытовых есть понятие названной, округленной, заявленной емкости. Законодательством разных стран разрешено в бытовой технике указывать округленные значения технических характеристик, которые порой отличаются от реальных на $10-15 \%$. К сожалению, все производители округляют заявленные значения в большую сторону. Это надо учитывать при подборе и сравнении БКН разных производителей. Реальные объемные значения определяются либо точными расчетами, либо замерами. При 
расчетном методе надо из геометрических размеров емкости вычитать объем, занимаемый внутренним спиральным трубчатым теплообменником. Обычно, объем трубчатого теплообменника занимает около $5 \%$ от общего внутреннего объема бака. Если учесть, что в бытовых БКН отличие габаритного объема от декларируемого отличаться на $10-15 \%$, то с учетом объема внутреннего теплообменника, это отличие может достигать $20 \%$.

Максимальная мощность теплообменника определяется при максимальном диапазоне перепада температур на входе в теплообменник (максимально допустимой температурой работы котла и минимальной температурой поступающей холодной воды). В большинстве случаев низкотемпературных отопительных приборов этот диапазон температур составляет 70 градусов. Зависит от материала теплообменника (змеевика) и площади теплообменника (диаметра, длина, толщина стенки).

$$
Q=\frac{\left(T_{\mathrm{r}}-T_{\mathrm{x}}\right) \cdot F}{R_{\mathrm{o}}}
$$

где $R_{\mathrm{o}}=\frac{1}{\alpha_{1}}+\frac{\delta}{\lambda}+\frac{1}{\alpha_{2}}-\begin{aligned} & \text { полное термическое сопротивление теплопереда- } \\ & \text { чи через однослойную плоскую стенку; }\end{aligned}$

$F$ - площадь поверхности теплообменника (змеевика);

$\frac{1}{\alpha_{1}}, \frac{1}{\alpha_{2}}-$ термические сопротивления теплоотдачи поверх-

$\frac{\delta}{\lambda}-$ термическое сопротивление стенки (толщина териала трубы).

Для примера возьмем теплообменник из гофрированной нержавеющей стали толщиной 0,3 мм. Длина трубы 15 м, площадь теплообменника $0,065 \cdot 15=0,975 \mathrm{~m}^{2}$, перепад температур $70^{\circ} \mathrm{C}$. теплопроводность $30 \mathrm{Bт} /\left(\mathrm{M}^{\circ}{ }^{\circ} \mathrm{C}\right), \alpha_{1}$ относительно спокойная вода - стенка $\alpha_{1}=500 \mathrm{BT}\left(\mathrm{M}^{2} \cdot \mathrm{K}\right)$, $\alpha_{2}=350+2100$ корень квадратный из скорости при $1,5 \mathrm{M} / \mathrm{c}$ примерно равно 3000 , тогда

$$
\begin{gathered}
R_{\mathrm{o}}=\frac{1}{500}+\frac{0,0003}{30}+\frac{1}{3000}= \\
=0,002+0,0001+0,0003=0,0024 ; \\
Q=70 \cdot 0,975 / 0,0024=28473 \text { Вт }(28,47 \text { кВт }) .
\end{gathered}
$$


В реальности дело обстоит гораздо скромнее. Температура в бойлере, первоначально повышается достаточно быстро, при достижении комнатной температуры в бойлере, максимально возможная мощность падает в рассматриваемом случае до $22 \mathrm{\kappa BT}$, при нагреве до $35^{\circ} \mathrm{C}-$ до 16,2 кВТ, а при нагреве до $50^{\circ} \mathrm{C}-10,1$ кВт.

Следовательно, нагрев до максимальной температуры замедляется и достижение максимальной температуры не возможно.

Можно подсчитать, какой расход воды может обеспечивать бойлер косвенного нагрева с таким теплообменником перейдя в равновесное состояние.

Допустим надо узнать, какова производительность бойлера при нагреве на $25^{\circ} \mathrm{C}$, с температуры 15 до $40^{\circ} \mathrm{C}$. При этом мощность теплообменника с параметрами, указанными выше. Будет равна 10,16 кВт. Тогда $10160 /(25 \cdot 1163)=0,35$ м³/ч или 5,8 л/мин $\left(1163\right.$ - теплоемкость воды в Вт/( м $\left.^{3 . \circ} \mathrm{C}\right)$.

То есть равновесное состояние данного теплообменника при подаче теплоносителя от котла с температурой $75^{\circ} \mathrm{C}$, будет составлять 5,8 л горячей воды с температурой $40^{\circ} \mathrm{C}$, при температуре холодной воды на входе $-15^{\circ} \mathrm{C}$.

Максимальное давление в теплообменнике. Трубы змеевика теплообменника, как правило, могут выдержать значительное давление, поскольку они выполняются из стандартных газоводопроводных или нержавеющих гофрированных труб, но подключены они к трубопроводам отопительных котлов, в которых есть ограничения на величину рабочего давления, равную 3 бара. Это обусловлено тем, что индивидуальные системы отопления имеют замкнутую систему с расширительными баками, рабочий диапазон у которых до 3 бар.

Поскольку, БКН соединены с системой отопления, то и значение максимального рабочего давления в змеевидном теплообменнике БКН будет 3 бара.

Максимальное давление в контуре ГВС. БКН входит в систему подготовки горячей воды индивидуального дома. Все элементы контура ГВС бойлера должны быть рассчитаны на рабочее давление стандартных систем ГВС, определяемые СНиП и равные для рабочего давления 6 бар и испытательное давление 10 бар.

Диапазон регулирования воды в бойлере косвенного нагрева задается термостатом, который, в свою очередь, управляет трехходовым краном (клапаном) котла. В целях исключения ожогов, при установке в частных домах, рекомендуется устанавливать верхний порог температуры воды в бойлере не выше $65^{\circ} \mathrm{C}$, в дошкольных учреждениях, такой порог может 
быть установлен на уровне $35^{\circ} \mathrm{C}$. В режимах длительного отсутствия потребления и исключения замерзания, можно установить порог выключения в 10 градусов. а порог включения бойлера в $5^{\circ} \mathrm{C}$.

Потери напора в трубе БКН. Потери напора можно определить по формуле

$$
h=\lambda \frac{L}{D} \frac{V^{2}}{2 g}
$$

Для нашего рассматриваемого случая

$$
h=\frac{0,02 \cdot 15 \cdot 1,5 \cdot 1,5}{0,02 \cdot 2 \cdot 9,81}=1,72 \text { метра, }
$$

где $h$ - потеря напора в метрах водного столба;

$\lambda$ - коэффициент гидравлического трения, находится дополнительными формулами о которых опишу ниже;

$L$ - длина трубопровода, м;

$D$ - внутренний диаметр трубы, м;

$V$ - скорость потока жидкости в трубопроводе змеевика, м/с;

$g$ - ускорение свободного падения, равен $9,81 \mathrm{~m} / \mathrm{c}^{2}$.

Время остывания воды в БКН при отсутствии ее потребления определяется термоизоляцией корпуса и теплопередачей через места подсоединения трубопроводов. Толщина теплоизоляции в БКН не такая большая, как в тепловых аккумуляторах, обычно она составляет 30 мм для настенных бойлеров и 40-50 мм для напольных. Теплопотери БКН составляют около 100 Вт/ч. При полезной мощности 5-8 кВт остывание до комнатной температуры происходит за 2 суток.

\section{3. Подбор параметров бойлера косвенного нагрева для потребителя}

Как было показано выше, объем потребления горячей воды на одного пользователя составляет до 130 литров в сутки. Если в помещении проживает 4 человека, то общее потребление горячей воды составляет в сутки 520 литров. Но нужен ли такой бойлер, чтобы обеспечить комфортное пользование горячей водой в доме? 
Конечно, нет! Если в вас в доме один душ и один кухонный кран, то, сколько бы людей не проживало, одновременно пользоваться можно только двумя этими точками разбора. Режим жизни людей разный и между потреблением горячей воды возникают паузы, в которые вода в бойлере подогревается.

В табл. 5 представлены значения расходов горячей воды основных сантехнических приборов с учетом температуры. А в табл. 6, объем потребления горячей воды в зависимости от количества людей, постоянно проживающих в помещении и состава сантехнических приборов.

Таблица 5

Расходы горячей воды в сутки на человека для основных сантехнических приборов

\begin{tabular}{|l|c|c|c|}
\hline \multicolumn{1}{|c|}{ Место водоразбора } & $\begin{array}{c}\text { Примерный } \\
\text { расход воды (л) }\end{array}$ & $\begin{array}{c}\text { Обычная } \\
\text { температура }\end{array}$ & $\begin{array}{c}\text { Расход воды } \\
\text { при } t=60^{\circ} \mathrm{C}(\text { л) }\end{array}$ \\
\hline Кухонная мойка & от 10 до 20 & $50^{\circ} \mathrm{C}$ & от 8 до 16 \\
\hline Ванна & от 150 до 180 & $40^{\circ} \mathrm{C}$ & от 90 до 108 \\
\hline Душ & от 30 до 50 & $37^{\circ} \mathrm{C}$ & от 16 до 27 \\
\hline Раковина & от 10 до 15 & $37^{\circ} \mathrm{C}$ & от 5 до 8 \\
\hline Мойка для рук & от 2 до 5 & $37^{\circ} \mathrm{C}$ & от 1 до 3 \\
\hline
\end{tabular}

Та блица 6

Объем потребления горячей воды для различных комбинаций сантехнических приборов и количества пользователей в доме (квартире)

\begin{tabular}{|c|c|c|c|c|}
\hline $\begin{array}{c}\text { Количество } \\
\text { членов семьи }\end{array}$ & \multicolumn{4}{|c|}{ Потребление горячей воды, литры } \\
\hline 1 & кухонная мойка & мойка для рук & душ & ванна \\
\hline 2 & 10 & 2 & 30 & 100 \\
\hline 3 & 15 & 4 & 55 & 120 \\
\hline 4 & 20 & 6 & 80 & 150 \\
\hline 5 & 30 & 8 & 110 & 200 \\
\hline 6 & 35 & 10 & 120 & 250 \\
\hline 7 & 50 & 12 & 150 & 340 \\
\hline 8 & 55 & 12 & 160 & 340 \\
\hline
\end{tabular}


Определим размеры БКН на конкретном примере.

В помещении проживает 4 человека и оно оборудовано тремя точками разбора горячей воды: ванной с душем, кухонной мойкой и краном с горячей водой в туалете. Тогда, по табл. 6, получаем $30+8+200=238$ литров. Значит, потребление горячей воды в расчетном случае составит 238 литров горячей $\left(60^{\circ} \mathrm{C}\right)$ воды в сутки, а не 520 литров, как это определяется из нормативов потребления горячей воды для коммунального потребления по СНиП.

Объем водонагревателя определяется по формуле:

$$
W=H \cdot \frac{T-T_{\mathrm{x}}}{T_{6}-T_{\mathrm{x}}},
$$

где $H$ - расход воды системы ГВС, определенный для конкретного случая потребления, л;

$T$ - температура горячей воды, потребляемая пользователем (можно принять равной $40^{\circ} \mathrm{C}$ );

$T_{\mathrm{x}}$ - температура холодной воды, можно принять равной $10^{\circ} \mathrm{C}$;

$T_{\sigma}$ - температура подготовленной бойлером горячей воды. принимаем $65^{\circ} \mathrm{C}$.

Для рассматриваемого нами случая,

$$
W=238 \cdot \frac{40-10}{65-10}=130 \text { литров. }
$$

Чтобы чувствовать себя более комфортно, выбирайте бойлер из существующих моделей с объемом, ближайшим к определенному, с округлением в большую сторону (в БКН бытового назначения практикуется завышение технических характеристик до 20\%). В нашем примере, это бойлер с объемом 150 литров.

БКН подогреваются теплоносителем отопительных котлов или тепловых аккумуляторов. Как правило, котлы имеют достаточную мощность для подогрева горячей воды, в табл. 7 показаны минимальные значения мощности котла, для выполнения комфортного пользования БКН подсчитанного по рекомендациям подбора объема БКН. Указанных выше. Если данная мощность не обеспечивается, то в некоторых случаях температура может быть ниже комфортной. К примеру. Если все 4 человека решат принять ванную подряд один за другим. 
Обращаем внимание, что пользование индивидуальными системами отопления и ГВС накладывает определенные требования к их эксплуатации. Можно создать систему очень мощную, но она будет дорогая, кроме того, основное время она будет недогружена и работать с низким КПД. Если не выдвигать очень жесткие и завышенные требования к мощности системы, то эксплуатация ее будет значительно дешевле. Объясним это на простом примере. Если поставить жесткое требование, чтобы вода в ГВС была всегда очень горячая и между принятием ванны двумя людьми подряд было не более 1 минуты, то надо ставить и мощный котел и большой водонагреватель. Но, если вы допустите, что интервал между принятием ванны двумя людьми подряд может быть более 10 минут (пауза на нагрев воды БКН), то можно применить и котел меньшей мощности и БКН меньшего объема. А это приведет к значительно меньшей стоимости оборудования.

Таблица 7

Минимальная мощность котла для обеспечения характеристик бойлера косвенного нагрева

\begin{tabular}{|c|c|}
\hline Бойлер косвенного нагрева, л & Мощность котла, кВт \\
\hline 80 литров & не менее 12 кВт \\
\hline 100 литров & не менее 14 кВт \\
\hline 120 литров & не менее 20 кВт \\
\hline 140 литров & не менее 20 кВт \\
\hline 200 литров & не менее 30 кВт \\
\hline
\end{tabular}

При работе БКН вся энергия нагрева котла идет на подогрев горячей воды. В этот момент отопление не получает тепловой энергии и дом остывает. Поскольку дома имеют большую массу и инерционность, то отсутствия отопления в течение нескольких минут никак не скажется на температуре в помещении. Но если 5 человек будут в ванной комнате мыться подряд по полчаса и пользоваться максимально горячей водой, то отопления не будет работать два с половиной часа, и это при низких температурах и недостаточной теплоизоляции дома, будет заметно. Есть два варианта решения этого 
вопроса. Ставить большой котел за большие деньги или просто между потреблением горячей воды делать паузу несколько десятков минут. Решение принимает Заказчик.

Мощность БКН, как и любого емкостного теплового аккумулятора, определяется по формуле (1).

При этом, нижний порог температуры зададим $35^{\circ} \mathrm{C}$, а верхний $75^{\circ} \mathrm{C}$ - максимальная возможная температура теплоносителя в отопительных приборах традиционных котлов. При объеме 150 литров, полезная мощность БКН равна

$$
Q=m \cdot C \cdot\left(T_{\max }-T_{\min }\right)=150 \cdot 4200 \cdot(75-35) / 3600=7000 \mathrm{BT}^{(7 \mathrm{\kappa B}) .}
$$

Ориентировочно, можно определить время набора полной полезной мощности БКН, если использовать полностью мощность отопительного котла на нагрев горячей воды, в примере с БКН 150 литров и мощности котла 20 кВт, время нагрева будет 21 минута.

\section{Площадь теплообменника}

Котел производит тепловую энергию в виде нагретого теплоносителя, который движется в трубопроводе с определенной скоростью с помощью циркуляционного насоса. Тепловая энергия передается воде БКН через стенки спирального трубопровода, расположенного в нем. Вопрос в размере площади внутреннего теплообменника и способности передать тепловую энергию теплоносителя за время его движения.

Для предварительного расчёта необходимых параметров теплообменника БКН подойдёт формула расчета площади теплообменника:

$$
F=L \cdot D=\frac{Q}{\left(T_{\text {г }}-T_{\mathrm{x}}\right) \cdot 3,14},
$$

где $F$ - площадь теплообменника, м $^{2}$

$L$ - длина трубки, м;

$Q-$ необходимая тепловая мощность змеевика (табл. 7);

$D$ - диаметр трубки, м;

$T_{\text {г }}$ - температура горячей воды, ${ }^{\circ} \mathrm{C}$;

$T_{\mathrm{x}}$ - температура холодной воды, ${ }^{\circ} \mathrm{C}$. 
В последнее время широкое распространение получили внутренние спиральные теплообменники из гофрированной нержавеющей трубы. При равном с гладкими трубами диаметре, их полезная площадь теплообмена в два раза больше.

\section{Дитература по главе 2}

1. СНиП 2.04.01-85. Внутренний водопровод и канализация зданий. 


\section{ЗАКЛЮЧЕНИЕ}

Повышение эффективности теплогенерирующих установок за счет утилизации теплоты, использования энергии возобновляемых источников, ее аккумулирование и последующее использование в системах отопления и ГВС в моменты «пиковой нагрузки», является актуальной задачей, стоящей перед наукой и промышленными предприятиями.

Тепловые аккумуляторы позволяют оптимизировать энергопотребление. Можно выбрать режим работы энергетической установки (котел) при максимальном КПД ее работы. В большинстве случаев, это режимы с избытком энергии, который можно направить на зарядку теплового аккумулятора. При отключенном котле, обогрев помещения будет происходить от заряженного аккумулятора. Тоже происходит при наличии устройств возобновляемых источников энергии, например, солнечных коллекторов. Летом, Солнце восходит в рано утром, а потребление тепловой энергии, для ГВС начинается обычно в 7-8 утра. Тепловая солнечная энергия раннего утра может быть заряжена в тепловом аккумуляторе и использована по мере необходимости в более позднее время.

По типу процесса аккумулирования энергии в тепловых аккумуляторах различают:

- тепловое аккумулирование энергии твердыми и жидкими телами за счет изменения температуры вещества - однофазная, емкостная аккумуляция;

- тепловое аккумулирование энергии посредством использования теплоты фазового перехода;

- термохимическое аккумулирование тепловой энергии.

Тепловые емкостные аккумуляторы, нашли широкое применение в народном хозяйстве. В них используются различные дешевые теплоаккумулирующие материалы, например, вода. Агрегатное состояние ТАМ в них не меняется во всем рабочем диапазоне. Зарядка и разрядка характеризуется исключительно переменной температурой. Данный тип ТА имеет низкую эффективность. Низкая теплоемкость ТАМ данного типа компенсируется большим объемом устройства. Однако, большие размеры TEA, необходимые для обеспечения разрядки в течение 5-7 часов для помещений более 100 квадратных метров, приводят к трудностям монтажа и эксплуатации этих систем. Стоимость таких устройств из-за большого размера, также достаточно велика. 
Второй тип устройств - аккумуляторы теплоты фазового перехода, основан на использовании обратимого процесса фазового перехода плавление - затвердевание. В качестве ТАМ для этих устройств, применяются материалы с изменяющимся фазовым состоянием в диапазоне температур эксплуатации системы. Конструкции ТА данного типа более сложные и дорогие, но в них на единицу объема запасается больше энергии, чем для тепловых аккумуляторов первого типа, причем процесс зарядки и разрядки в них происходит в очень узком диапазоне температур.

Наиболее пригодными для низкотемпературных АФП считаются парафины. Достоинства парафинов:

- большая теплота фазового перехода;

- отсутствие эффекта переохлаждения;

- низкий коэффициент вязкости;

- парафин, в жидком состоянии неполярная жидкость и поэтому не смешивается с полярными, такими как вода и спирт.

- низкая электропроводность;

- долговечен и стабилен при циклическом изменении агрегатного состояния;

- температура воспламенения выше $250^{\circ} \mathrm{C}$;

- стабильность при нагреве до $250^{\circ} \mathrm{C}$;

- не кипит, нет опасности возникновения высокого давления пара даже при высоких рабочих температурах;

- экологически безвреден;

- не токсичен, не вреден для здоровья;

- являются коррозионно устойчивыми материалами.

Плотность термических парафинов в жидком состоянии колеблется от 750 до 850 кг $/ \mathrm{M}^{3}$ и в твердом от 800 до 900 кг $/ \mathrm{M}^{3}$. Перечисленные свойства парафина делают его идеальным материалом для различных приложений, связанных с низкотемпературной аккумуляцией теплоты.

Главным и существенным недостатком парафинов - низкий коэффициент теплопроводность в твердой фазе и изменение плотности при фазовом переходе.

Если рассматривать эффективный диапазон изменения рабочих температур ТА, то мощность водяного ТАМ при объеме кубический метр, составляет 23 кВт, а парафинового, 52 кВт. Разница в 2,26 раза.

В низкотемпературных ТА также используют кристаллогидратные термо аккумулирующие материалы. К важному недостатку данных ТАМ можно отнести их повышенную коррозионную активность, к преимушествам - более высокие показатели удельные мощностные характеристики.

Третий способ аккумулирования тепловой энергии термохимический. Он основан на использовании обратимых химических реакций 


\section{A.A. Торопов}

и позволяет запасать тепловой энергии на единицу массы больше, чем в первых двух случаях, но сложен в реализации в системах отопления и ГВС, в настоящее время, практически, не применяется.

Бойлеры косвенного нагрева имеют конструктивные сходства с тепловыми аккумуляторами и отличия.

\section{Общее:}

- одинаковое конструктивное решение, состоящее из емкостного бака, теплоизоляции, внутреннего теплообменника, патрубков подключения, магниевого анода, узлов контроля и управления;

- внешний источник энергии в виде нагретого теплоносителя.

Различия:

- в качестве аккумулирующего материала в БКН применяется только вода, качество которой соответствует сантехническим нормам «Питьевая вода», поскольку назначение БКН подготовка воды для ГВС конечного потребителя. В тепловых аккумуляторах может быть любой теплоаккумулирующий материал. Все бойлеры косвенного нагрева - емкостного типа с внутренним теплообменником;

- уровень рабочего и испытательного давлений воды в БКН соответствует требуемому СНИП давлениям систем ГВС, в то время, как тепловые аккумуляторы могут быть безнапорными и иметь атмосферное рабочее давление;

- объем БКН определяется количеством точек разбора горячей воды (душевые, кухни) в помещении и количеством жителей, проживающих в нем. БКН имеют значительно меньший объем, чем ТА;

- БКН имеют меньшую толщину термоизоляции корпуса, поскольку нет необходимости хранить тепловую энергию длительное время. Объем БКН относительно небольшой и температура в нем может быть восстановлена достаточно быстро;

- БКН занимают значительно меньше места, чем ТА, выполняются в настенном и напольном вариантах, размещаются в кухнях, ванных, туалетах. К их внешнему виду, из-за места их размещения, предъявляются более высокие требования.

Можно сказать, что бойлер косвенного нагрева, это специализированное применение теплового аккумулятора для подготовки воды в системе горячего водоснабжения конечного потребителя.

Учебное пособие «Комбинированные тепловые гелиосистемы. Часть 2. Тепловые аккумуляторы, бойлеры косвенного нагрева для индивидуальных и децентрализованных систем отопления и горячего водоснабжения» предназначено для помощи в изучении и создании высокоэффективных энергосберегающих систем отопления и ГВС». 


\section{СПИСОК ИСПОЯЬЗОВАННОЙ ЯИТЕРАТУРЫ}

1. Торопов А.Л. Комбинированные тепловые гелиосистемы. Ч. 1. Тепловые солнечные коллекторы для индивидуальных и децентрализованных систем отопления и горячего водоснабжения: учебное пособие. М.: Издательский дом Академии Естествознания, 2019. - 88 с.

2. СНиП 2.04.01-85. Внутренний водопровод и канализация зданий.

3. Бекман Г., Гилли П. Тепловое аккумулирование энергии. М.: Мир, 1987.

4. Kreith F., Kreider J.F. Principles of Solar Engineering. - Washington, London, 1978. - 778 p.

5. Левенберг В.Д., Ткач М.Р., Гольстрем В.А. Аккумулирование тепла. - К.: Техника. 1991. - 112 с.

6. Физические величины: справочник / под ред. И.С. Григорьева, Е.3. Мейлихова. - М.: Энергоатомиздат, 1991. - 1232 с.

7. Справочник химика / под ред. Б.П. Никольского. - Л., 1967. -622 c.

8. Боровская Л.В., Шабалина С.Г. Теплоаккумулирующие свойства природных и синтетических восков // Современные наукоемкие технологии. - 2010. - № 4. - С. 98-99.

9. Цимбалюк Ю.В. Методика расчета фазопереходных тепловых аккумуляторов для нефтегазопромысловых объектов // Вестник АГТУ. 2006. - № 6 (35). - C. 98-100. 
Учебное издание

Торопов Алексей Леонидович

\section{КОМБИНИРОВАННЫЕ ТЕПЛОВЫЕ ГЕЛИОСИСТЕМЫ}

\section{Часть 2}

Тепловые аккумуляторы, бойлеры косвенного нагрева индивидуальных и децентрализованных систем отопления и горячего водоснабжения

Учебное пособие

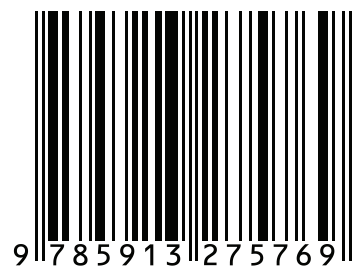

Технический редактор Кулакова Г.А.

Подписано в печать 14.03.2019

Бумага офсетная.

Гарнитура NewtonC

Формат $60 \times 841 / 16$

Печать трафаретная. Печ. л. 2,75.

Тираж 500 экз. Заказ № 008-19.

Отпечатано в типографии ИД «Академия Естествознания», 440026, г. Пенза, ул. Лермонтова, 3 